\title{
Lumen
}

Selected Proceedings from the Canadian Society for Eighteenth-Century Studies

\section{Rewriting Romance: Elizabeth Hamilton's Memoirs of Modern Philosophers and Jane Austen's Northanger Abbey}

\section{Megan Taylor}

Volume 31, 2012

URI : https://id.erudit.org/iderudit/1013075ar

DOI : https://doi.org/10.7202/1013075ar

Aller au sommaire du numéro

Éditeur(s)

Canadian Society for Eighteenth-Century Studies / Société canadienne d'étude du dix-huitième siècle

ISSN

1209-3696 (imprimé)

1927-8284 (numérique)

Découvrir la revue

Citer cet article

Taylor, M. (2012). Rewriting Romance: Elizabeth Hamilton's Memoirs of Modern Philosophers and Jane Austen's Northanger Abbey. Lumen, 31, 169-181.

https://doi.org/10.7202/1013075ar d'utilisation que vous pouvez consulter en ligne. 


\section{Rewriting Romance: Elizabeth Hamilton's Memoirs of Modern Philosophers and Jane Austen's Northanger Abbey}

Megan TAYlor

University of Ottawa

Elizabeth Hamilton's Memoirs of Modern Philosophers (180o) and Jane Austen's Northanger Abbey (1817) are novels about novels. Each seems to challenge popular sentimental and Gothic fiction in the same way, by ridiculing or debunking their melodramatic romantic conventions. But Austen's criticism is far less savage than Hamilton's, which is unforgiving in its treatment of romance. Austen, by contrast, pokes affectionate fun at romantic formulas to revise without rejecting them, while Hamilton's very rigidity of purpose makes it difficult for her to maintain a consistency of representation. Even as she attempts to expose the weaknesses of romantic excess, Hamilton frequently finds it necessary to resort to those very conventions in order to heighten the suspense or emotional impact of her own plot. Austen's more intentionally inclusive approach is not marred by these kinds of inconsistencies, and this difference lends an authority to Austen's criticism that is somewhat undermined in Hamilton's. Ultimately, this difference also illuminates the contrast between each author's sense of her reading public, and the way in which she engages in the act of fiction. Austen's deft renovation of romantic convention demonstrates a faith in her readers, and in romance, that Hamilton's more contradictory and inflexible approach precludes.

In her anti-Jacobin novel Memoirs of Modern Philosophers, Hamilton's critique is most squarely aimed at the tenets of the "New" or "Modern Philosophy," which emerged in the late eighteenth century 
as a set of revolutionary ideals championed by such radicals as William Godwin and Thomas Paine. Claire Grogan explains that, like many conservative writers, Hamilton worried that this new ideology promoted "selfish, romantically self-indulgent and obsessive behaviour." By identifying romance as one of the pernicious qualities Hamilton deplores in the "New Philosophy," Grogan flags the ancillary target of Hamilton's satire: the novel. In Memoirs the term "novel" is a disapproving label applied strictly to the eighteenth century's more sensational works of literature: romance, melodrama, sentimental fiction. While Hamilton's work is primarily seen as a critique of incendiary politics or philosophy, it also attacks such literature on the same grounds as it attacks Jacobin doctrine. Hamilton connects the two as both romanticize "the individual's rights and caprices," ${ }^{2}$ and she considers that this romanticism can have a dangerously destabilizing effect on a reader; in her later history Memoirs of Agrippina, Wife of Germanicus, Hamilton writes of novels that "the brilliant illusions of fancy may affect the sensibility of the heart, and so far captivate the understanding as to render it unwilling to exert itself in detecting the fallacy of arguments which have spoken so powerfully to the feelings."

In Memoirs, Hamilton sets about deflating this romantic fallacy through her narrator's sarcastic running commentary on the ridiculous implausibility of novelistic conventions. She peppers the novel with moments that seem to promise the dramatic episodes expected by romance readers, and then disappoints those expectations by portraying a more "realistic" version of events. Bridgetina's coach journey is mundane, contrary to the novelistic commonplace that "an heroine could not travel twenty miles, without encountering so many strange incidents, that the reader no sooner had notice of her having mounted her horse, than his imagination was upon the spur for some great event." Henry Sydney, young and hardy, recovers steadily from a serious indisposition despite the fact that "a dangerous fit of illness would

1. Elizabeth Hamilton, Memoirs of Modern Philosophers, ed. Claire Grogan (Toronto: Broadview, 2000), 237 (hereafter cited as MMP).

2. MMP, 16 .

3. Elizabeth Hamilton, Memoirs of Agrippina, Wife of Germanicus, (London: Cruttwell, 1804), http://books.google.ca/books?id=oJM2PFYIoy8C\&pg=PA118\&dq= $\%$ 22memoirs+of+ agrippina.

4. MMP, 237. 
in his circumstances have been vastly more becoming, and much more

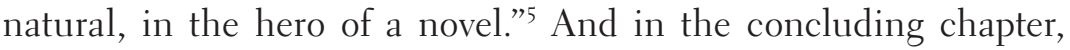
Hamilton mockingly predicts and then frustrates her reader's hope that all the characters will be happily married off, claiming a more realistic position for her work than that of the romantic comedy which ends in weddings for all.

In a less lighthearted vein, Hamilton continues this attack on novelistic convention through two of her principal characters, Bridgetina Botherim and Julia Delmond. The former has the dubious honour of providing comic relief throughout the novel, and so her fate is less severe than Julia's. But both girls, avid novel readers, are punished for misguidedly aspiring to live the melodramatic life of the heroines that people their favourite books. In Bridgetina, Hamilton punctures the convention of the peerless romantic heroine found in any Radcliffe or Lewis novel by creating her opposite. As an anti-heroine, and as a nasty caricature of contemporary radical novelist Mary Hays, Bridgetina is not just ordinary but superlatively unpleasant: she is short, scrawny, and crooked; she has a shrill voice, a scraggly neck and a lazy eye; she is selfish, improper, and completely lacking in selfawareness or common sense. Yet thanks to her voracious reading habits, Bridgetina models herself on the impossible paragons of femininity in romantic fiction. In the grotesque disparity between her heroine's imagined charms and actual qualities, Hamilton's satire is at its cruelest, a bitter attack on the impropriety and implausibility of novelistic conventions. All of Bridgetina's numerous attempts to behave like the heroines she admires are thwarted by the prosaic and sometimes unpalatable realities of everyday life. Each time Bridgetina begins to rhapsodize about her tormenting passion for her lover, as every proper sentimental heroine ought to do, she is prematurely cut off by various, but invariably ordinary, events: her mother's peevish reprimands; an unruly herd of pigs; the rude jostlings of a crowded London street. ${ }^{6}$ By allowing the mundane not only to interrupt but to replace Bridgetina's narratives in this way, Hamilton shows that such flights of fancy are inconsistent with reality. Their inappropriateness, moreover, is heightened by the reader's awareness that Bridgetina's

\footnotetext{
5. MMP, 347 .

6. MMP, 119, 157, 303.
} 
musings over the consuming love that she and Henry Sydney share are not grounded in fact but are pathetically adrift in self-delusion. Henry, along with the rest of the novel's more discerning characters, has nothing but pitying contempt for Bridgetina.

The censure of the polite world is bad enough, and Hamilton makes it clear that to act on selfish and implausible desires is to court universal disdain. The sensible Maria Sydney speaks for herself, her friends, and implicitly the reader when she condemns Bridgetina's pursuit of Henry to London as "shameful. . . absurd... and preposterous"; several people whom Bridgetina encounters on her travels even conclude that she is mad. ${ }^{8}$ But Bridgetina exposes herself to more serious consequences than that of a damaged reputation. Traveling around London unaccompanied, with insufficient money and no knowledge of the city or of human nature, Bridgetina is variously robbed on the street, wrongly arrested, and almost imprisoned. Hamilton is careful to demonstrate that not only are Bridgetina's romantic ideals incompatible with truth and common sense, but they can also lead to genuine danger.

Julia Delmond is the principal sufferer of the real evils that Bridgetina only glimpses, and this is the more serious figure in Hamilton's satire of romantic convention. Although she is beautiful, generous, and sensible - the quintessential romantic heroine and the very opposite of Bridgetina - Julia's unchecked reading of novels and romances ultimately proves fatal:

In vain did [Julia's] reason revolt at the absurdities which abounded in these motley tales; in the kindling passions of her youthful bosom they found a never-failing incentive to their perusal. Imagination, wild and ungoverned imagination reigned paramount in her breast. The investigation of truth had no longer any charm. Sentiment usurped the place of judgement, and the mind, instead of deducing inferences from facts, was now solely occupied in the invention of extravagant and chimerical situations. ${ }^{9}$

This passage is perhaps the novel's most absolute condemnation of romance, claiming that such escapist reading teaches young people,

7. MMP, 291.

8. MMP, 240, 260.

9. MMP, 86. 
who are intellectually and emotionally vulnerable, to shun "the investigation of truth" in favour of false sentiment, of "extravagant and chimerical situations." Hamilton uses Julia to demonstrate what disasters can come of such privileging of the imagination. Faced with the mystery of her lover Vallaton's parentage, Julia draws on the conventions of sentimental fiction to concoct elaborate fantasies about his noble birth. She unquestioningly believes his amorous professions as they correspond with her idea of how a hero and a lover should behave. As a result, Julia is persuaded to elope with a man who proves himself to be a rogue and a liar; she is ruined, robbed, abandoned, and almost sold into sexual slavery, escaping only to die repentant in an unmarried mothers' and destitutes' charitable home. This is the fate of romance in Memoirs: Julia and Bridgetina stand in for romance readers, and Hamilton shows that the best they can hope for in the real world is humiliation and censure, and the worst they must fear is ruin and death.

Thus, over the course of Memoirs, Hamilton consistently posits that romantic expectations are not only silly and inaccurate but harmful, and that the novels that promulgate them are in this respect dangerous. How, then, do we reconcile Hamilton's message with her medium? For Memoirs is, of course, an instance of the very literary form that Hamilton attacks. Some critics do not see this as a problem: The AntiJacobin Review in September 1800 wrote of Hamilton that "the public is infinitely obliged to her... for... having given [her critique] in the form of a novel; for the same means by which the poison is offered, are, perhaps, the best by which their antidote may be rendered efficacious." ${ }^{10}$ This reviewer obviously makes an important distinction between the corrective satire of Hamilton's novel and the romantic fiction she is writing against. There is some evidence, however, that Hamilton herself had doubts about this distinction, and about the corrective power of fiction. She writes that any "work of the imagination," regardless of its nature,

may be so managed, as to be admirably calculated to promote the reception of a favourite theory, but can never be considered as a confirmation of its truth. Nor will the theory built upon such a basis be of

10. Anti-Jacobin Review and Magazine 7 (December 1800), in Appendix C of Memoirs of Modern Philosophers, ed. Claire Grogan (Toronto: Broadview, 2000), 409. 
long duration... the chasm will at length be broken, and then the system which had been supported by its influence, will inevitably sink into disgrace. ${ }^{.1}$

Thus Hamilton creates an even more problematic paradox for herself: not only has she written a novel whose "favourite theory" is an attack on other novels, but she then also writes of novels that their theories cannot be trusted. This conflict seems to have worked its way into the text of Memoirs, for its negative opinion of romance is compromised by its frequent, and apparently sincere, use of the conventions of sensational fiction it at other moments decries.

We have already seen how Hamilton has laughed at the idea that Henry, a healthy young man, should suffer a relapse of his illness simply because it would be more romantic for him to do so. ${ }^{12}$ And yet, only a few pages earlier, this is exactly what has happened. Henry is recovering well from a minor injury when he discovers that he has a new rival for the affections of his beloved Harriet, and this realization sends him into an immediate decline: "Trifling was the pain of the wound [Carradine's] hand had given, in comparison of that which his conduct now inflicted on the heart of Henry... When Doctor Orwell went to enquire for his young friend on the following morning, he... received intelligence of Henry's increased indisposition," which progresses until Henry finds himself in "the utmost danger." 13 The idea that a mild injury should become a life-threatening illness through the hero's jealousy for his beloved is a familiar one in melodramatic romance, and Hamilton capitalizes upon it here even as she debunks it elsewhere. Deliberately amplifying the pathos created by Henry's illness, Hamilton spends pages describing the anguished suffering of Henry's friends anticipating the worst.

Similarly romantic and equally unrealistic are Julia's final appearance and the novel's conclusion. In a coincidence that would honour the most sensational fiction, Julia's fatal illness brings her to the very charitable institution that belongs to Mrs. Fielding, the hostess and intimate acquaintance of Julia's closest friends. And in an ending that would do justice to the most melodramatic romance, every character

11. Hamilton, Agrippina, xi.

12. MMP, 347 .

13. MMP, 333 . 
in Memoirs gets what he or she deserves: Julia, the repentant fallen woman, dies absolved by her friends and by God; Vallaton, the irredeemable villain, is executed; the less culpable sinners Bridgetina, Mr. Myope, and Mr. Glib, are put on the road to redemption, and the four virtuous young people are rewarded with happy marriages. The neat and implausible poetic justice of this ending undermines Hamilton's claim that she offers a more realistic version of life than does romance. And her apparent dependence upon the very conventions of romantic fiction that she attempts to satirize further destabilizes the critique she levels against them.

Austen's Northanger Abbey, on the face of it, takes a similar critical position to Hamilton's Memoirs as it too is apparently preoccupied with mocking Gothic novels and their conventions. The novel begins with the teasingly anti-Gothic characterization of Catherine Morland, much like that of Bridgetina Botherim. She is at once declared to be the heroine of the piece and yet described in exceedingly unheroic terms. The novel opens with the tongue-in-cheek assertion that, "no one who had ever seen Catherine Morland in her infancy, would have supposed her born to be an heroine."14 Austen's narrator continues to describe Catherine along the same mocking, unromantic lines: "she had a thin awkward figure, a sallow skin without colour, dark lank hair, and strong features... She was fond of all boy's plays, and greatly preferred cricket not merely to dolls, but to the more heroic enjoyments of infancy, nursing a dormouse, feeding a canary-bird, or watering a rose-bush." ${ }^{15}$ Here Austen, like Hamilton, if less severe, subjugates the extravagant qualities of a romance heroine to the commonplace attributes and interests of a real little girl. Throughout the novel, Austen at first seems as consistently as Hamilton to deny both reader and (mock)heroine alike the melodramatic events of romance in order to privilege the realism of the everyday. Like Bridgetina and Julia, Catherine's love of Gothic fiction nourishes her expectations for romance in real life, and she is continually disappointed by her discoveries. The hoped-for gloomy, ancient abbey proves to be a modern English home; a mysterious chest and cabinet yield nothing

14. Jane Austen, Northanger Abbey, ed. Claire Grogan (Toronto: Broadview, 2002), 37. Hereafter cited as NA.

15. NA, 37-8. 
but prosaic linen and bills for the same; and the evil patriarch suspected of "murdering or shutting up his wife" turns out to be not a lustful bandito but a mere greedy snob. ${ }^{16}$

Many critics and readers have understood this deflation of romance as a straightforward condemnation similar to Hamilton's. Catherine must learn to suppress her imaginative desire for the Gothic and accept the realities of ordinary life. ${ }^{17}$ We should, however, be wary of taking Austen's ridicule at face value after encountering the startlingly emphatic intercession of her narrator, who defends the very novels that she proceeds to mock; novels, writes Austen in this famous passage, are works "in which the greatest powers of the mind are displayed, in which the most thorough knowledge of human nature, the happiest delineation of its varieties, the liveliest effusions of wit and humour, are conveyed to the world in the best chosen language."18 This seeming paradox - a novel that both defends and makes fun of novels - is also reminiscent of Hamilton's work, and has led some critics to dismiss Northanger Abbey as self-contradictory or self-defeating ${ }^{19}$ much like, as I have argued, Hamilton's Memoirs.

I would contend, however, that in Austen this seeming contradiction exists on a superficial level only, and that Northanger Abbey is engaged rather in a complex effort of reconciliation. Austen mocks certain aspects of Gothic fiction to demonstrate how novelistic conventions are not literal representations, but reflections - distorted, but potentially illuminating, reflections - of everyday truths. Claudia Johnson describes the renovating approach of Austen's parody, arguing that

Austen's mock-gothic juxtaposes the 'alarms of romance' to the 'anxieties of common life' in order to enable us to see their interdependence. Rather than merely asserting the reality of one and dismissing the nonreality of the other... we see them each anew, and we are struck first by

16. NA, 236.

17. See, for example, Patricia Meyer Spacks, "Muted Discord: Generational Conflict in Jane Austen" in Jane Austen in a Social Context, ed. David Monaghan (Totowa: Barnes \& Noble, 1981), 172; Stuart M. Tave, “The Expectations of Catherine Morland" in Some Words of Jane Austen (Chicago: U of Chicago P, 1973), 62.

18. NA, 6o.

19. See, for example, George Levine, "Translating the Monstrous: Northanger Abbey," Nineteenth-Century Fiction 30, no. 3 (Dec. 1975): 338-40, http://www.jstor. org/stable/2933073. 
their apparent distinctness and next by their apparent indistinguishability. ${ }^{20}$

In the development of Austen's heroine, in the undercurrent of real evil and danger that can be sensed in some of the novel's most mundane events, and in the positive use to which Catherine puts some of her Gothic sensibilities, Austen shows how, properly adjusted, romance can be a powerful medium of interpretation and a source of real improvement and pleasure for its readers.

As we have earlier seen, Austen takes great pains to describe the unheroic qualities of Catherine Morland. Austen seems to suggest that since Catherine has none of the elaborate trappings of the romance heroine, she must be the opposite, an extremely ordinary girl. But over the course of the novel, as we become more acquainted with Catherine, we realize that this dichotomy is too simple. Catherine is far from ordinary; in fact she possesses all the qualities that make her a heroine, if a heroine of the everyday: she has a delicate but unaffected sense of propriety and deference for authority; ${ }^{21}$ she is principled but never obstinate, ${ }^{22}$ she is kind and good-natured; ${ }^{23}$ and she is variously described as displaying "the real delicacy of a generous mind" and speaking with "simplicity and truth, and without personal conceit." 24 Despite the accusations of ignorance and naivety from many readers and critics, Catherine possesses from the outset of the novel a sound intuitive sense. Although in her kindness she gives the benefit of the doubt to the obnoxious John Thorpe, the coquettish Isabella, and the disingenuous Captain Tilney, she is never truly deceived by them. Catherine notes John Thorpe's boorishness on first meeting him, she very early identifies the marks of selfishness and greed in Isabella, and she understands the impropriety of Captain Tilney's addresses to her friend. ${ }^{25}$ Taken together, these qualities show that although Catherine is far from the histrionic heroine of Gothic fiction, she is equally far from ordinary.

20. Claudia L. Johnson, introduction to Northanger Abbey, eds. James Kinsley and John Davie (Oxford: OUP, 2003), xiv-v.

21. NA, 118-19.

22. NA, 114.

23. NA, 141.

24. NA, 77, 91.

25. NA, 72, 79, 106, 113-14, 154 . 
Much like Catherine's supposed naivety, too much has been made of Gothic fiction's negative influence over her. It is certainly true that Catherine's reading of such romances affects her response to certain external stimuli: she is eager to visit ruins and abbeys, and she has exaggerated hopes about the interest an antique chest or a dark cabinet might hold. But these are mere superficialities, purely aesthetic preoccupations. When it comes to important matters - to judging people and to assessing situations - Catherine's reading never leads her astray. Contrary to the dictates of Gothic fiction, when she sees Henry Tilney accompanied at an assembly by a strange woman, Catherine rationally concludes that this woman is his sister, whom he has mentioned, and not a love interest, since he has never alluded to one. So instead of “turning a deathlike paleness, and falling in a fit on Mrs. Allen's bosom, Catherine sat erect, in the perfect use of her senses, and with cheeks only a little redder than usual."26 When Catherine's Gothic fantasies lead her to suspect General Tilney of some horrible crime, it is true that she has not grasped the complex reality of the situation, but neither has she entirely misjudged the General. When his actual faults come to light - his greed in courting Catherine for a daughter-in-law when he supposed her to be rich, and his shocking, even dangerous discourtesy in expelling her from the Abbey when he discovers her to be poor - it is Henry, and not Catherine, who is surprised. Henry Tilney - commonly considered the novel's bastion of order and common sense $\mathrm{e}^{27}$ and the one who rebukes Catherine for her outlandish suspicions of his father - is the one who has misjudged: "Henry, in having such things to relate of his father, was almost as pitiable as in their first avowal to himself. He blushed for the narrow-minded counsel which he was obliged to expose."28

Indeed, throughout the novel Henry attempts to dispel the sense of the Gothic that colours Catherine's vision of the world. But while at certain moments it seems as though Henry's common sense dominates the narrative, Austen arranges these moments so that the reader retains a feeling of Gothic unease that is no longer associated with the "alarms of romance" but with the "anxieties of common life." For example,

26. NA, 75-76.

27. See, for example, Levine, "Translating," 340; Tave, "Catherine," 56.

28. NA, 236. 
Henry mocks Eleanor and Catherine for misunderstanding one another when Catherine obscurely alludes to the publication of a new Gothic horror novel and Eleanor thinks she is describing actual civil violence. Henry laughingly dismisses the issue, but the reader is left to consider authorship and anarchy side by side; this confusion is also, as Johnson points out, "an insight, as both riots and gothic novels evoke the terror of moral anarchy." ${ }^{29}$ Similarly, when Henry chastises Catherine for her outrageous suspicions of his father, he implores her to "remember that we are English, that we are Christians...Could [such atrocities] be perpetrated without being known, in a country like this, where social and literary intercourse is on such a footing; where every man is surrounded by a neighbourhood of voluntary spies, where roads and newspapers lay every thing open?"30 Such a reproof has, at least temporarily, its intended effect on Catherine, who determines to abandon her "visions of romance" forever. ${ }^{31}$ But the reader, again, is left to ponder the potentially sinister implications of living "surrounded" by "voluntary spies." This sense of unease increases when the General shows his true colours. Although not a murderer, he nevertheless exposes Catherine to very real danger when he expels her from his house and forces her on a seventy mile journey unaccompanied and, as far as he knows, penniless. Catherine's "visions of romance" which lead her to suspect the General in the first place are thus modified, yet justified; Catherine feels that "in suspecting General Tilney of either murdering or shutting up his wife, she had scarcely sinned against his character, or magnified his cruelty."32 Northanger Abbey's juxtaposition of the frightening with the mundane emphasizes the shades of grey in every character and situation, and shows that a Gothic sensibility is a helpful tool to detect such nuances.

Ultimately, the influence of Catherine's Gothic reading proves to be more beneficial to her than not. As we have seen, it provides a medium through which she can understand General Tilney that, while distorted, is nevertheless closer to the truth than her natural diffidence and respect for authority might have allowed her to come. But more than a lens of interpretation, Catherine's novel reading also offers a

29. NA, xv.

30. NA, $195-96$.

31. NA, 196.

32. NA, 236. 
source of harmless pleasure and even independence. When Isabella tries to convince her that she would pine away - in high romance heroine fashion - if Henry Tilney left Bath for good, Catherine stoutly and cheerfully replies, "No, indeed, I should not. I do not pretend to say that I was not very much pleased with him; but while I have [The Mysteries of] Udolpho to read, I feel as if nobody could make me miserable." ${ }^{33}$ Catherine, although she is hardly aware of it, derives strength and insight from her Gothic reading, and thus, while Austen might send up its extravagances, she subtly affirms its power and positive influence.

In this way Austen's burlesque of Gothic fiction is a more complex, and more successful, criticism than Hamilton's attack on romance. Austen, while mocking the melodramatic excesses of Gothic fiction, also identifies its truth by adapting its conventions to suit, and even to explore, the workaday world of middle-class England. Hamilton, on the other hand, strenuously resists any such reconciliation; she attempts to privilege an entirely romanceless reality, yet inconsistently relies upon the conventions of romance she rejects. Thus we can see a striking difference in the scope and effectiveness of each author's critique, and from it we can extrapolate an understanding of each author's wider sense of fiction and its readers. Austen's heroine, even in her youth and innocence, can fearlessly peruse the pages of the wildest romance and emerge not only unscathed, but strengthened. This indicates that, as Johnson observes, "despite [a] concern with the dangers of fiction... Austen did not [have a] deep anxiety for the moral stability of readers, and... she relied more confidently on her audience's ability to read properly." 34 Hamilton's rigid and contradictory criticism reveals, by contrast, both an attraction to romance and yet, as Mark Phillips notes, a serious fear that "the novel... symbolizes the kind of loose exercise of the imagination that weakens the rational capacities in a young and uninstructed reader." 35 Austen and Hamilton represent not only differ-

33. NA, 63.

34. Claudia L. Johnson, "The 'Operations of Time, and the changes of the Human Mind': Jane Austen and Dr. Johnson Again” in Jane Austen: Critical Assessments, ed. Ian Littlewood, vol. 2 (London: Helm, 1998), 139.

35. Mark Salber Phillips, “'If Mrs. Mure Be Not Sorry for Poor King Charles': History, the Novel, and the Sentimental Reader," History Workshop Journal 43, (Spring 1997): 121, http://www.jstor.org/stable/4289493. 
ent views of romance, but different views of romance's readers. And yet in their broader concern with the impact of reading, these authors are also united - they share a common interest in fiction not only as a means to entertain, but as a force to influence and instruct, for better or for worse. 